\title{
The Economic Geography of Human Capital in Twentieth-Century Latin
} \section{America}

\author{
Enriqueta Camps ${ }^{1} \&$ Stanley Engerman ${ }^{2}$ \\ ${ }^{1}$ Universitat Pompeu Fabra and Barcelona GSE, Spain \\ ${ }^{2}$ University of Rochester, USA \\ Correspondence: Enriqueta Camps, Universitat Pompeu Fabra and Barcelona GSE, Spain.
}

Received: November 18, 2016

Accepted: December 8, 2016

Online Published: January 2, 2017

doi:10.5430/ijfr.v8n1p112

URL: http://dx.doi.org/10.5430/ijfr.v8n1p112

\begin{abstract}
In this paper we present results for educational achievement in the different economic regions of Latin America (Big countries: Mexico and Brazil; Southern Cone; Andean countries; Central America; and others) during the twentieth century. The variables we use to measure education are average years of education, literacy, average years in primary school, average years in secondary school, and average years in university. To attain a broader perspective on the relationship of education with human capital and with welfare and wellbeing we relate the educational measures to life expectancy and other human capital variables and GDP per capita. We then use regressions to examine the impact of race and ethnicity on education, and of education on economic growth and levels of GDP per capita.

The most significant results we wish to emphasize are related to the importance of race and racial fractionalization in explaining regional differences in educational achievement. Southern Cone countries, with a higher density of white population, present the highest levels of education in average terms, while countries from Central America and Brazil, with a higher proportion of Indigenous Americans and/or blacks, have the lowest levels. In most countries the major improvements in educational achievement are: the expansion of primary education during the first half of the twentieth century, and the expansion of secondary education after 1950. In all cases, average years in university are low, despite improvements in university quality during the last decades of the century when professors exiled during dictatorships returned to their countries of origin.

International comparisons (continental averages for years of education weighted by country population size) place twentieth-century Latin America in an intermediate position between the USA and Europe at the top, and countries from Asia and Africa at the bottom.
\end{abstract}

Keywords: Latin America, international comparative approach, education, race

\section{Introduction}

Historically, research into human capital shows a general consensus that its formation has been unequal among individuals and groups, within and across countries. This fact has had further consequences for patterns of economic performance. Education and human capital formation have had a large impact on economic growth through their impact on skills and the ability to innovate and diffuse innovation. The leading scholars on human capital formation (Becker1964; Lucas 2002; Barro 2012) have considered this variable as an endogenous variable. Only when a certain level of GDP per capita was achieved could education develop further. Growth and higher incomes led to better education. But in developing countries the opposite causal relation may also be true, in which educational improvement is an exogenous variable that leads to further economic growth. An historical example of this second causal relation in Latin American countries was the spread of mass education during the "Estado Docente" years that fostered economic growth in the "Desarrollismo" period (Frankema 2009, Abad 2016).

In any case, the appropriateness of education systems depends on the structure of industries and on the economic structure in general. In agrarian societies and in societies where industries only developed the technologies of the first industrial revolution, education has played just a minor part in economic growth, having a lesser role than that of health, physical strength and height, as has been recently empirically shown for Spain (Camps, 2016).

On the other hand the spread of education also depends on educational and income inequality (Baten, Mumee 2010; Alvaredo, Gasparini 2015). Recent results for developing countries show that in the late $20^{\text {th }}$ century, from 1970 to 
2010, within-country income inequality showed a slight increase while levels of poverty decreased sharply (Sala-i-Martin 2006, Alvaredo and Gasparini 2015). According to Sala-i-Martin (2006) the period 1970-2000 was also one of economic convergence in world equality. Inequality sharply diminished across countries thanks to economic growth of developing countries, mainly the world's most highly populated countries of South and East Asia.

Income inequality has additional effects on educational performance. People belonging to the highest income percentiles of the population can afford to pay more for education and do not depend on laboring by their children, so they can further develop their skills while people from the lowest percentiles cannot. Nonetheless, there is an intergenerational effect in this relation. Parents' incomes influence education and, in turn, their children's incomes (Balcazar, Narayan, Tiwari 2015, see also Baizan and Camps 2007 for the influence of father's income and mother's education levels on their children's education in $20^{\text {th }}$-century Spain). On the other hand, the educational supply and amount of education an individual can afford will depend on the social and ethnic group they belong to. With regard to the effect of race and ethnicity, recent studies demonstrate the importance of segmentation of the educational supply according to race. While in some cases this kind of inequality has tended to diminish in the last decades of the $20^{\text {th }}$ century (Engerman and Sokoloff 2102; Camps and Engerman 2016; Bucciferro 2014). racial and ethnic discrimination in access to education has major repercussions on the incomes, wages, and occupations of ethnic group members.

In this paper we analyze the economic geography of human capital (education and health) in $20^{\text {th }}$-century Latin America with special reference to education. In order to make feasible comparisons we group Latin American countries into economic regions: Big countries -Mexico and Brazil-; the Southern Cone; Andean countries; Central America, and others (see the appendix for the details of the countries in each group). In terms of economic geography, only Southern Cone countries belong to the temperate climate area, while most of the other countries belong to the tropical area with the corresponding economic growth outcomes (tropical epidemics, high temperatures that yield good returns in production, and negative environmental effects). We think that while these economic regions share a lot of common characteristics in terms of social organization, ethnic identity and culture are important when explaining human capital evolution.

In order to present the first results, based on the educational structure, we need to consider the quantity of education (average years of schooling) versus the quality of schooling (e.g. expenditure on schooling). While we were able to collect most of these variables in quantitative terms we have had to rely on the available literature regarding its quality (Reimers 2006; Frankema 2009; Bertola, O'Campo 2013; Valente, Berry 2015). In the figures and tables in the appendix, we also present performance according to education levels: primary (elementary, grades 1-8) leading to the improvement of literacy levels and basic knowledge; secondary (high school, grades 9-12); and tertiary (university levels). These education stages are sequential and, therefore, more years of schooling means higher levels of education.

We must also consider that how much education individuals receive does not strictly depend only on personal choice, at least in developing countries. They are subject to constraints such as income level, parental income, urban or rural residence, and gender (Balcazar, Narayan, Tiwari 2015). They also depend on legislative and judicial influences that may or may not foster the enforcement of education, such as government spending at different levels (state, local, federal), what amount is compulsory and for how many years, and subsidies for potential students (Engerman and Sokoloff 2012; Engerman and Camps 2016; Balcazar, Narayan, Tiwari 2015). Last but not least, education is also influenced by suffrage, and the number of overseas migrants (Alvaredo, Gasparini 2015).

Inequality in human capital formation has varied among Latin American nations and regions and could be an important factor influencing economic growth. The recent literature suggest that it is only after certain levels of health and education are achieved that the impact of human capital accumulation on economic development becomes important.

\section{Data Sources and Methodology}

In this paper we use the main variables to measure human capital, levels of education and information on GDP per capita. Data on human capital are from the dataset leaded by Jan Luiten Van Zanden, Clio Infra. Data on levels of education are from Barro and Lee (2010) and data on GDP per capita are from the last results presented by the Maddison group. Data on race are from Rosemblat (1945) and Alesina et alt (2003). 
Measuring the impact of human capital on economic growth is a complex task since this variable is endogenous. This is why in the last part of the paper we present a natural experiment based in a reduced sample of Latin American countries. But quantitative results for all countries are presented in section 3 of the paper.

\section{The Evolution of Human Capital during the Twentieth Century in Quantitative Terms}

In the figures and tables in the appendix we present the data on the evolution of human capital variables, in terms of both education and health, in Latin American countries. Figures presented are in Stata format. Tables in the appendix also present results based on the international comparison, at the continental level, of educational achievement weighted by country population size. An initial result that should be stressed is that during the $20^{\text {th }}$ century all human capital variables improved throughout Latin America. All variables related to schooling (years of education, educational ginis, illiteracy, years in primary school, years in secondary school, years in university) and health (height, life expectancy) improved in all Latin American countries. The levels in 1900 were low, so there was much room for improvement, but the importance of this result is nevertheless worth highlighting. In spite of periods of bad economic conditions, economic indebtedness and other factors leading to economic turmoil (dictatorships, foreign emigration, etc....) the expansion of human capital was dramatic between 1900 and 2000. We will first examine the basic data on schooling, literacy, and educational ginis; then proceed to the analysis of education levels; and also discuss changes in health.

In Figures 1, 2 and 3 we present the results for the main variables representing the development of education.

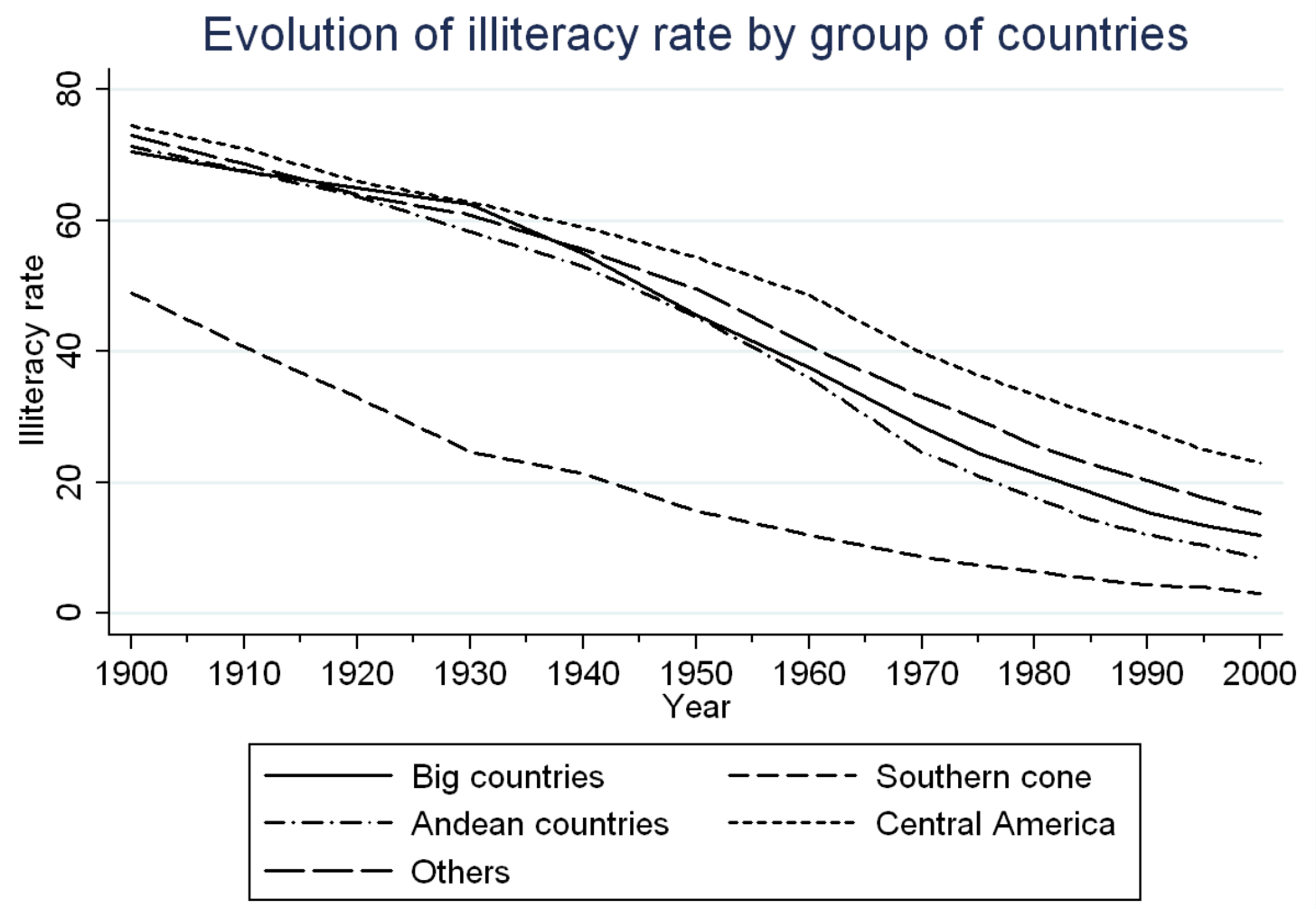

Figure 1 


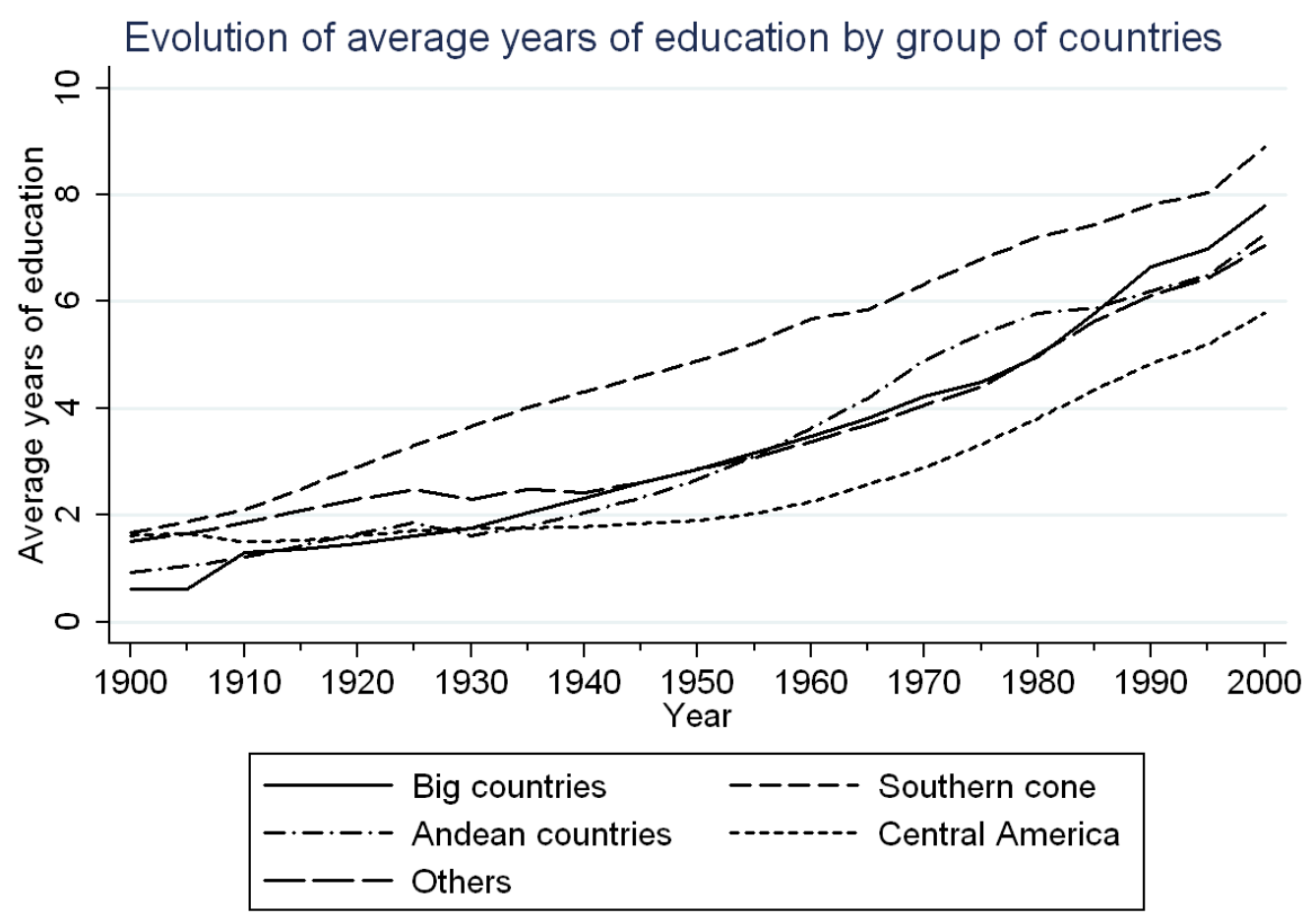

Figure 2

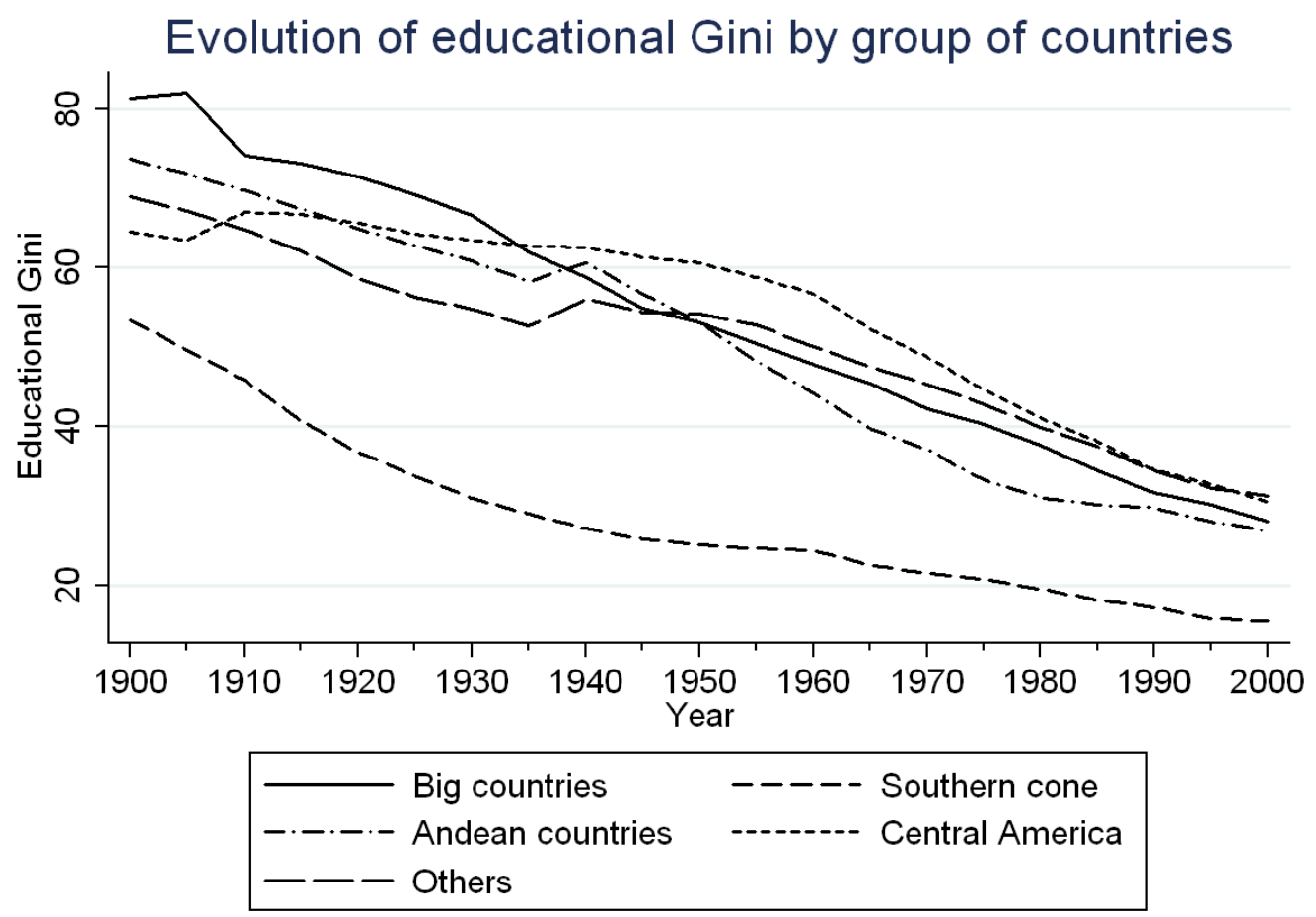

Figure 3 
In these figures we see a common trend, independent of income levels and in all economic regions, of a diminution in illiteracy levels, an increase in average years of education, and a decrease in the educational Gini. With the exception of Southern Cone countries, which have been the most successful, in all other economic regions illiteracy levels diminish from around 70\% in 1900 to levels around 20\%-40\% in 2000; average years of education increase from 1 or 2 in 1900 to 5-7 in 2000. As illiteracy decreased and education expanded, the educational Gini diminished from $60 \%-80 \%$ in 1900 to $30 \%-40 \%$ in 2000 (5\% in the Southern Cone). Southern Cone countries had been in a better situation during the $19^{\text {th }}$ century. Since these countries received most of the European migration to Latin America already during the last third of the $19^{\text {th }}$ century, they had the highest density of urban white population and maintained their position in relation to other Latin American regions in the $20^{\text {th }}$ century.

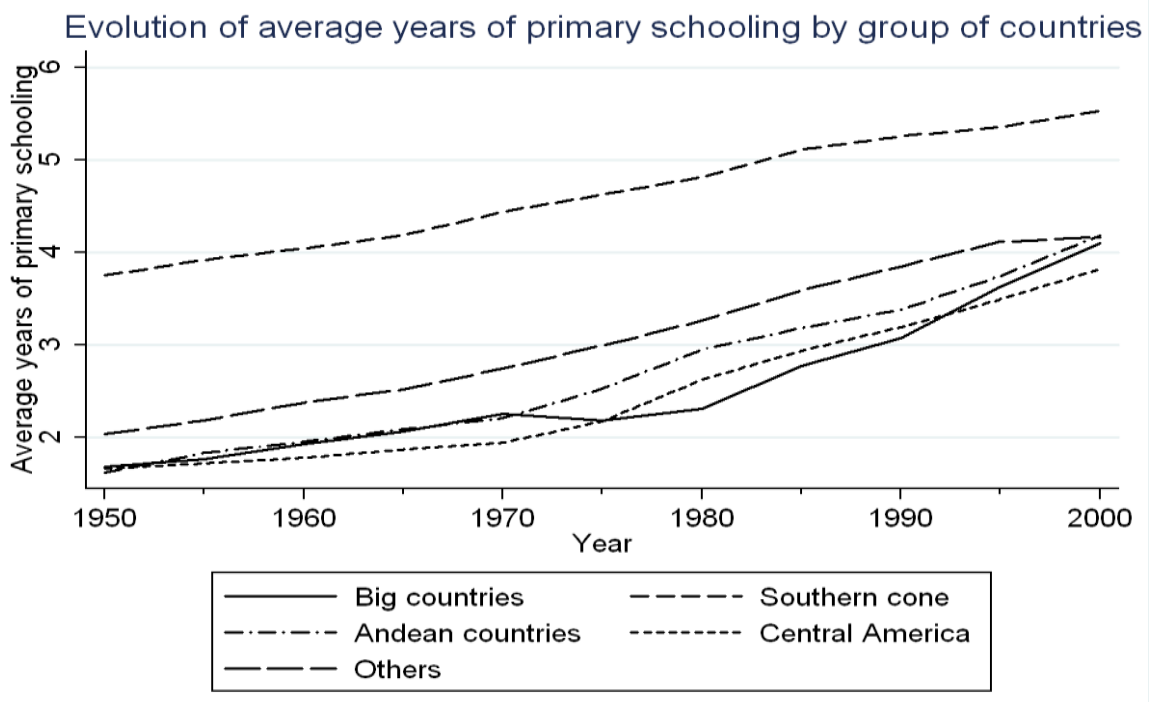

Figure 4

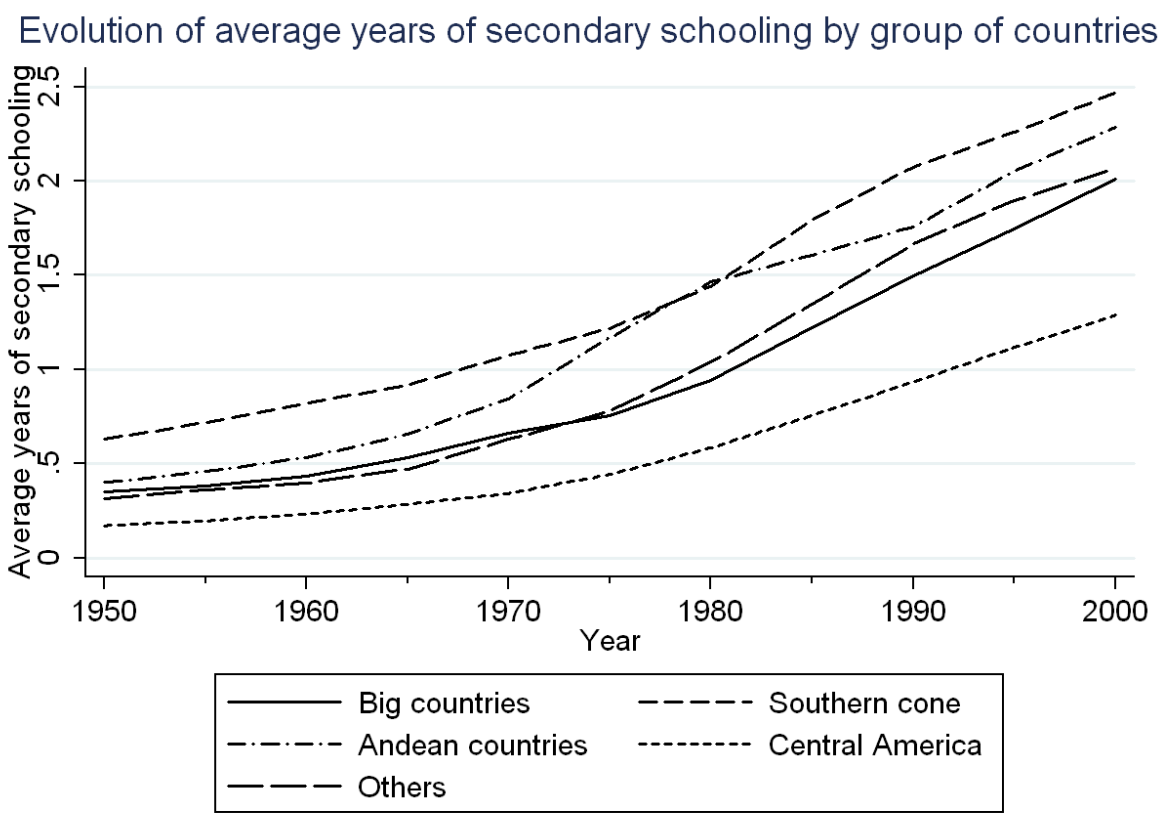

Figure 5 


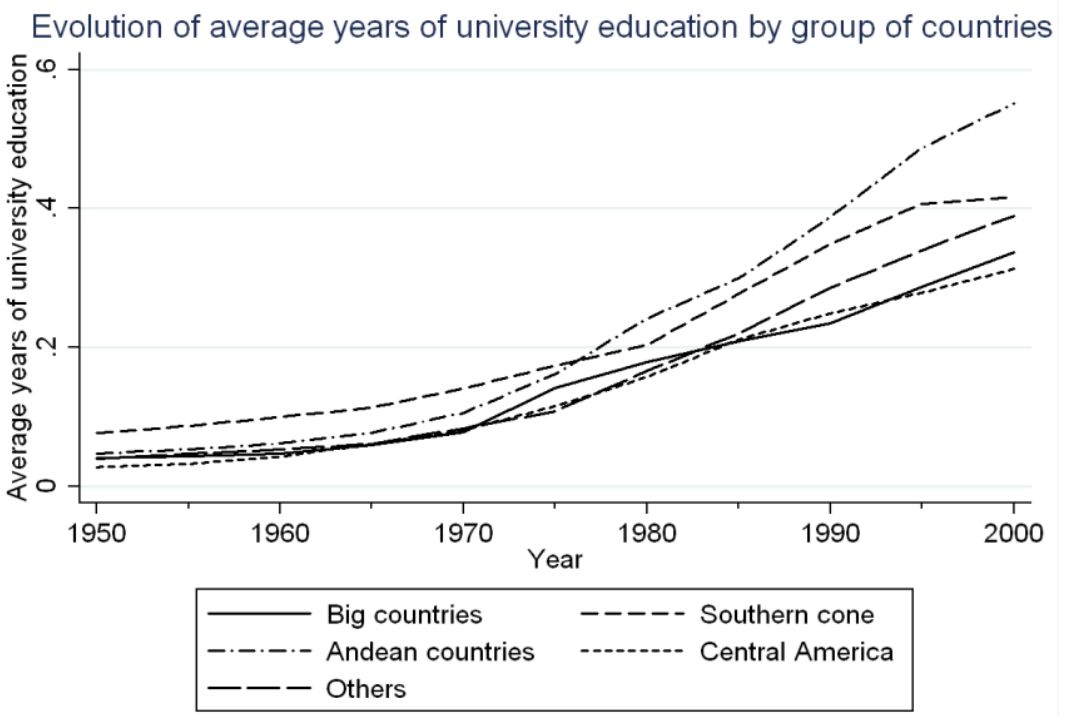

Figure 6

We present the results for each education level from 1950 to 2000. The years of education in primary schools has the greatest impact on illiteracy rates. Figure 1 indicates that, with the exception of Southern Cone countries, illiteracy rates were high the other countries in Latin America during most of the $20^{\text {th }}$ century. In spite of the fact that years in primary school show an upward trend, by the year 2000 they were less than four years in most countries, but five years in the Southern Cone. This means that throughout the $20^{\text {th }}$ century a large percentage of children did not complete primary education. Course repetitions and dropouts were frequent experiences that can explain the low number of years spent in primary school in most countries.

Years in secondary school and university show similar outcomes. Southern Cone and Andean countries have best performance, while Central America and the Big countries do the worst. Notice, in particular, that the average years of education in universities is less than one in all country groups, meaning that university attendance was poorly achieved, at least till the end of the $20^{\text {th }}$ century.

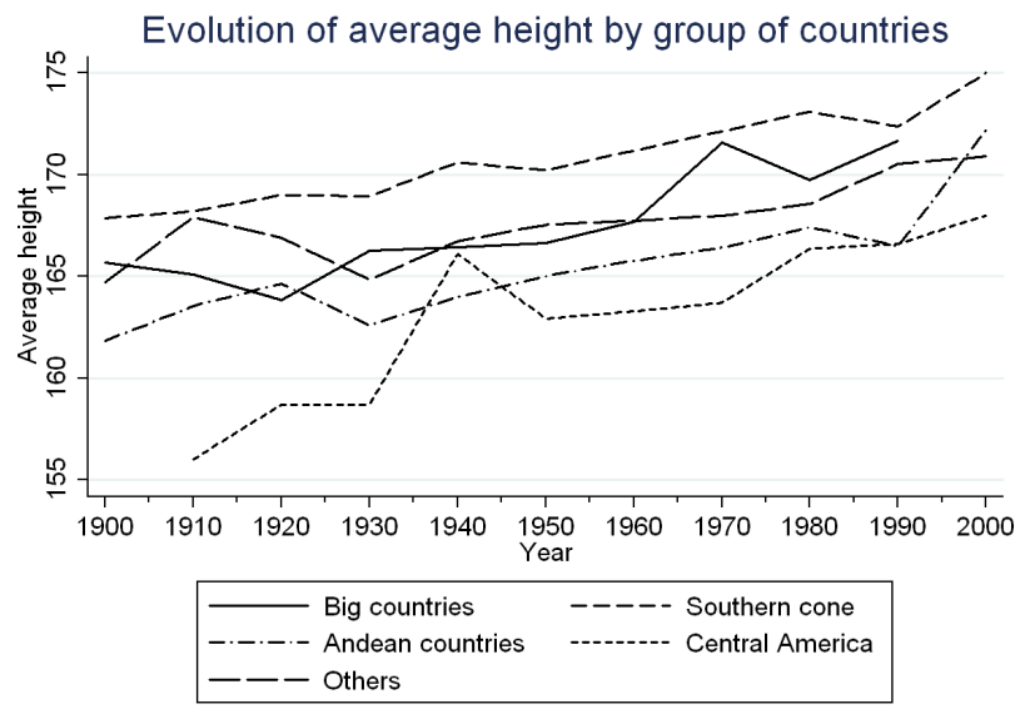

Figure 7 


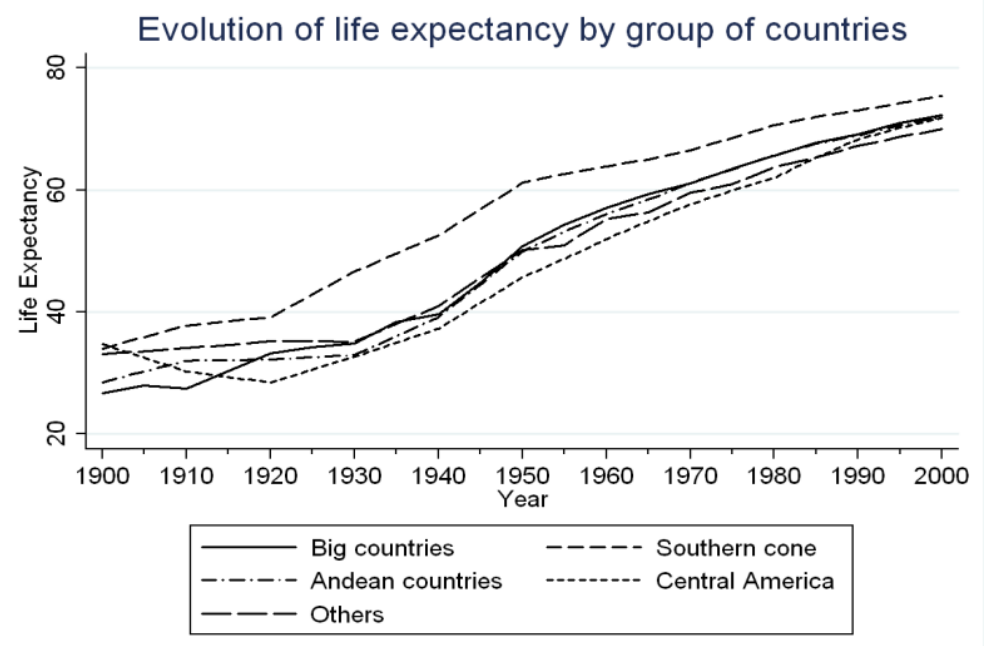

Figure 8

When we consider the evolution of other variables regarding human capital, including health variables, we again observe the superiority of Southern Cone countries. This group of countries not only consistently has the lowest illiteracy rates and lowest educational Gini, but also the highest life expectancy, tallest average height, and highest average years of education at primary, secondary and university levels. At the opposite end of the spectrum, Central America, with the highest proportion of blacks and/or indigenous Americans, has the highest illiteracy rate, lowest life expectancy, smallest heights, and, until the 1990s, the lowest enrollment rates in all three educational levels and the smallest decline in the educational Gini.

Thus the most striking differences are between the Southern Cone and Central America. Big countries (Mexico and Brazil) have a large growth in height and GDP per capita (see table), average years of education, and a relatively large decline in the educational Gini. Andean and other countries range somewhere around the middle.

We obtained similar results regarding the timing of the improvements observed in the figures and tables in the appendix. The earliest improvements began in Southern Cone countries, who lead in average years of education by 50 years, in primary education by 20 years, in the upswing in GDP per capita by 20 to 50 years; and in the increase in life expectancy by 10 years.

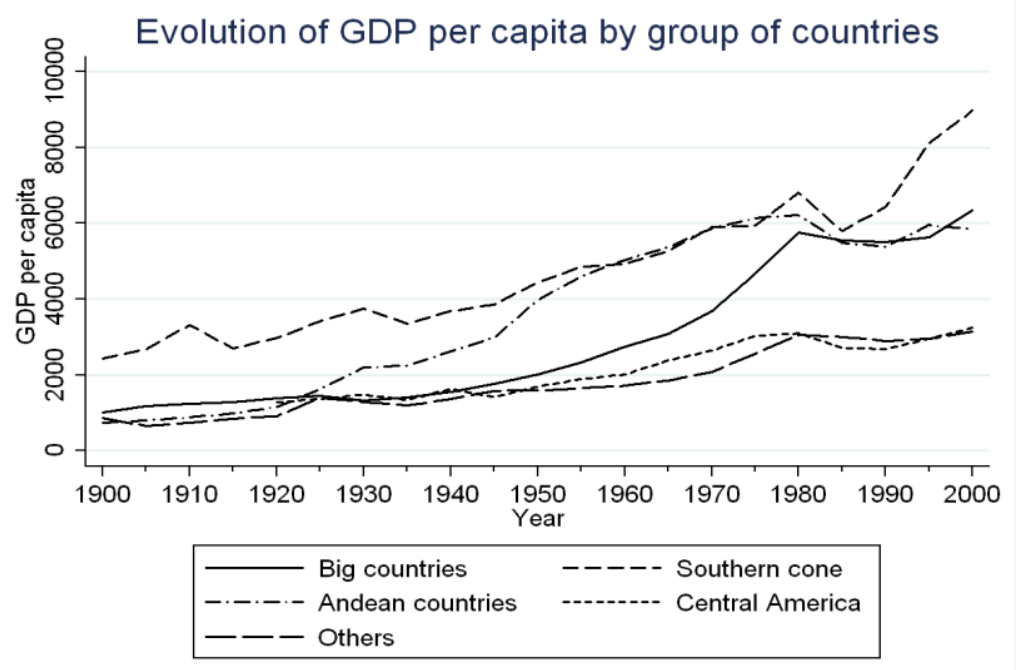

Figure 9 
These figures show that there are many issues that come into play regarding the nature of human capital in Latin American countries. Nonetheless, we can draw the conclusion that during the $20^{\text {th }}$ century there was a general trend of human capital improvement across all countries, although racial segmentation still exists. The standard of the education supplied to non-white populations from rural areas clearly needs further improvement.

\section{The Role of Race and Ethnicity in Educational Attainment}

There is a long history of ethnic and racial segregation in Latin America, which basically starts with the settlement by white Europeans mostly from Spain and Portugal but also from the Netherlands, Britain, and France. The initial settlement in lands in which Native-American Indians were resident, often led to assaults by Europeans to take land and to relocate the indigenous peoples. The arrival of Europeans diseases previously not known to the indigenous peoples of Latin America, led to a series of severe epidemics that resulted in a significant population decrease estimated by some to be about $80 \%$ within two centuries. The major outcome was that their social and political power was limited, and the lack of suffrage was reflected in lowered political influence, leading to fewer social services, including education. In several Latin American countries a limited labor supply to produce export commodities led to the importation of black slaves from Africa. Over time this led to large number of African-American slaves in Brazil, Venezuela, Cuba, and Colombia. After the nineteenth century abolitions of slavery, the ex-slave and the free new black population were not granted rights to benefit from education, and were restricted economically and politically by various legal and non-legal policies. These restrictions led to a much lower amount of schooling than for whites, as well as lower expenditures for schools and schooling than for whites in both rural and urban areas. Even after legislation to end this pattern in the second part of the twentieth century, differentials in the quantity and quality of education remained. Attempts in some nations to improve the situation of the indigenous populations led to some, but still limited, improvements.

Racial groups can be basically divided into two groups: whites (of different nationalities, native- born and migrants) and nonwhites (Native Americans -indigenous peoples- and African-Americans who came to the Americas as slaves). In terms of racial composition, we can group Latin American countries as follows:

a. Majority white (50\% or more): Costa Rica, Brazil, Uruguay, Argentina and Chile (the latter being $47.4 \%$ whites while Indigenous Americans plus Mestizos equalled 52.6\%, so that whites have not a clear majority)

b. Majority Indigenous American and Mestizos: Mexico, Guatemala, Honduras, Nicaragua, Panama, Colombia, Ecuador, Peru, Bolivia, and Paraguay.

c. Over 20\% black: Colombia, Venezuela, and Brazil.

In order to estimate the impact of race on education and per capita GDP we present the following regressions.

Table 1. Race, education and GDP per capita

\begin{tabular}{lccccc}
\hline & \multicolumn{2}{c}{1950} & & \multicolumn{2}{c}{2000} \\
\cline { 2 - 3 } \cline { 5 - 6 } & Av. years of education & ln GDP & & Av. years of education & ln GDP \\
\hline Indian & -0.002 & -0.004 & & 0.021 & 0.001 \\
White & $(0.017)$ & $(0.007)$ & & $(0.017)$ & $(0.006)$ \\
& 0.018 & 0.007 & & $0.027^{* *}$ & $0.010^{* *}$ \\
Black & $(0.011)$ & $(0.004)$ & & $(0.010)$ & $(0.004)$ \\
& -0.026 & -0.029 & & -0.023 & $-0.014^{* *}$ \\
Constant & $(0.071)$ & $(0.028)$ & & $(0.015)$ & $(0.006)$ \\
& $2.575^{* * *}$ & $7.652^{* * *}$ & & $6.269^{* * *}$ & $8.128^{* * * *}$ \\
Observations & $(0.702)$ & $(0.274)$ & & $(0.575)$ & $(0.225)$ \\
$R^{2}$ & 17 & 17 & & 20 & 20 \\
\hline
\end{tabular}

Standard errors in parentheses. Omitted category is race mixed.

$* \mathrm{p}<0.1, * * \mathrm{p}<0.05, * * * \mathrm{p}<0.01$

In Table 1 we only obtain statistically significant results for the year 2000, but the value and sign of the coefficient leaves little doubt as to the positive causal relation between percent white, education levels, and per capita GDP. Signs for Indigenous peoples are negative in 1950 and positive in 2000 but are not statistically significant. The coefficient for blacks is negative in both 1950 and 2000. These results demonstrate the inequality with regard to racial composition for both education and GDP per capita. 
Table 2. Race, education and GDP per capita

\begin{tabular}{lcccc}
\hline & $(1)$ & $(2)$ & $(3)$ & $(4)$ \\
& mean edu & mean edu & mean lgdp & mean lgdp \\
\hline Indian & -0.126 & -0.010 & -0.044 & -0.005 \\
& $(0.189)$ & $(0.020)$ & $(0.051)$ & $(0.006)$ \\
White & 0.156 & 0.010 & $0.047^{*}$ & $0.006^{*}$ \\
& $(0.099)$ & $(0.013)$ & $(0.027)$ & $(0.004)$ \\
Black & -0.363 & -0.042 & 0.038 & -0.022 \\
& $(1.226)$ & $(0.081)$ & $(0.330)$ & $(0.023)$ \\
Constant & 1.943 & $3.709^{* * *}$ & $6.934^{* * *}$ & $7.783^{* * *}$ \\
& $(4.251)$ & $(0.845)$ & $(1.146)$ & $(0.243)$ \\
\hline Observations & 33 & 33 & 33 & 33 \\
$\mathrm{R}^{2}$ & 0.214 & & 0.237 & \\
Fixed Effects & Yes & No & Yes & No \\
\hline
\end{tabular}

Standard errors in parentheses. Omitted category is race mixed.

There are two observations for each country: the average values in the first and second half of the XXth century, respectively.

${ }^{*} p<0.1, * * p<0.05, * * * p<0.01$

To further examine the results in Table 1, we have recalculated the regression in Table 2 where the values of years of schooling and per capita GDP are the average values of each country in the first and then the second halves of the century. Again the values and signs of the coefficients provide the same information as in the Table 1, although in this case we only obtain statistically significant results in the relationship between percentage white and per capita GDP.

To further explore the relationship between race, school attainment and per capita GDP growth we conducted a natural experiment with a sample of countries that had a similar evolution before the cutoff line of 1890 . The treatment countries are the Southern Cone countries, Argentina and Chile, with a majority white population, and the control countries are Brazil (more than 20\% black), and Colombia and Peru, with a majority of indigenous peoples and mestizos. As a result, we want to stress the differences between whites and nonwhites with regard to the impact of racial composition on education and per capita GDP growth.

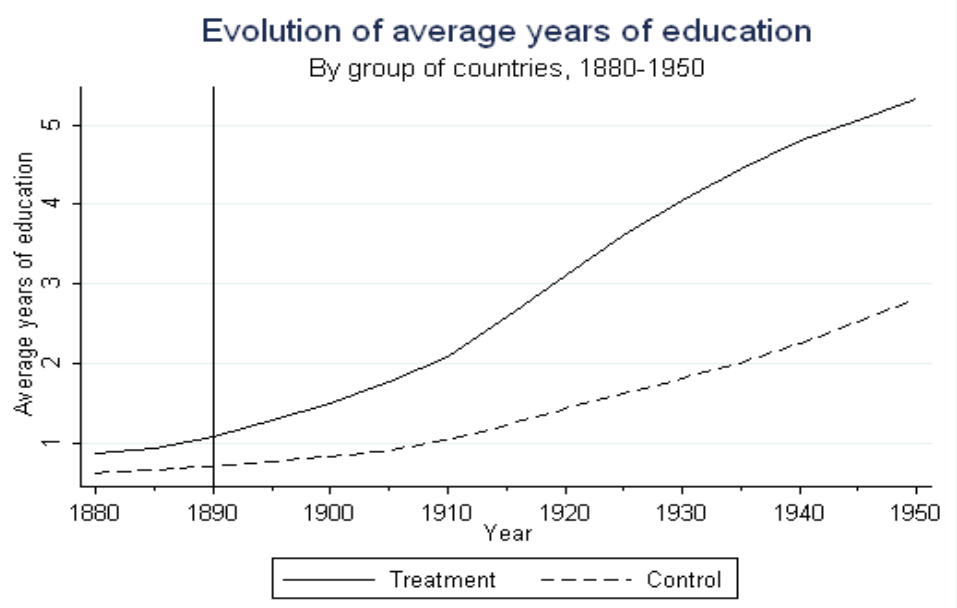

Figure 10. Diff-in-Diff - Small sample

Treatment countries are Argentina and Chile and control countries Brazil, Colombia and Peru. 
As Figure 10 illustrates, there are noteworthy educational differences between the treatment countries (Argentina and Chile) and the control countries (Brazil, Colombia and Peru), the increase in education being far greater in treatment countries, as was previously demonstrated in part 3 of this paper.

Table 3 presents the results at the first stage of our Diff-in-Diff analysis, in which we regress the average years of education on a dummy in the treatment group (i.e. group 1 countries), a dummy post (equal to 1 after 1890 , 0 otherwise) and the interaction between the two (the instrumental variable). The last column includes the whole sample while the other columns are for different sub periods. We can see that the implementation of primary schooling up to 1890 had a positive effect on average years of schooling where it was applied, as the TreatxPost coefficient is positive and significant.

Table 3. Primary schooling laws and education - Diff in diff Stage 1

\begin{tabular}{|c|c|c|c|c|c|}
\hline \multicolumn{6}{|c|}{ Average years of education } \\
\hline & $(1)$ & (2) & (3) & (4) & (5) \\
\hline \multirow[t]{2}{*}{ Treat } & 0.297 & 0.297 & 0.297 & 0.297 & 0.297 \\
\hline & $(0.201)$ & $(0.257)$ & $(0.415)$ & $(0.537)$ & $(1.121)$ \\
\hline \multirow{2}{*}{ Post } & $0.291 *$ & $0.370^{*}$ & $0.629 * *$ & $0.939 * *$ & $2.564 * * *$ \\
\hline & $(0.161)$ & $(0.199)$ & $(0.303)$ & $(0.380)$ & $(0.756)$ \\
\hline \multirow[t]{2}{*}{ Treat x Post } & $0.592 * *$ & $0.723 * *$ & $1.123 * *$ & $1.402 * *$ & 1.556 \\
\hline & $(0.254)$ & $(0.315)$ & $(0.480)$ & $(0.601)$ & $(1.195)$ \\
\hline \multirow[t]{2}{*}{ Constant } & $0.661 * * * *$ & $0.661 * * *$ & $0.661 * *$ & $0.661 *$ & 0.661 \\
\hline & $(0.127)$ & $(0.162)$ & $(0.263)$ & $(0.340)$ & $(0.709)$ \\
\hline Observations & 40 & 45 & 60 & 75 & 125 \\
\hline$R^{2}$ & 0.594 & 0.555 & 0.503 & 0.483 & 0.291 \\
\hline Sample & 1880-1915 & 1880-1920 & 1880-1935 & $1880-1950$ & $1880-2000$ \\
\hline
\end{tabular}

Standard errors in parentheses

Treatment group countries are Argentina and Chile, while control group countries are Brazil, Colombia and Peru $* \mathrm{p}<0.1, * * \mathrm{p}<0.05, * * * \mathrm{p}<0.01$

Table 4. Education and GDP per capita - IV results. Stage 2.

\begin{tabular}{|c|c|c|c|c|c|}
\hline \multirow{3}{*}{ Average years of education } & \multicolumn{5}{|c|}{ Ln of GDP per } \\
\hline & (1) & (2) & $(3)$ & (4) & $(5)$ \\
\hline & $\begin{array}{l}0.409 * \\
(0.226)\end{array}$ & $\begin{array}{c}0.276 \\
(0.173)\end{array}$ & $\begin{array}{l}0.070 \\
(0.130)\end{array}$ & $\begin{array}{l}-0.009 \\
(0.133)\end{array}$ & $\begin{array}{c}-0.160 \\
(0.309)\end{array}$ \\
\hline Post & $\begin{array}{l}-0.000 \\
(0.136)\end{array}$ & $\begin{array}{c}0.075 \\
(0.130)\end{array}$ & $\begin{array}{c}0.312 * * \\
(0.157)\end{array}$ & $\begin{array}{c}0.519 * * \\
(0.220)\end{array}$ & $\begin{array}{c}1.455 \\
(1.013)\end{array}$ \\
\hline Treat & $\begin{array}{c}0.947 * * * \\
(0.164)\end{array}$ & $\begin{array}{c}0.987 * * * \\
(0.147)\end{array}$ & $\begin{array}{c}1.048 * * * \\
(0.161)\end{array}$ & $\begin{array}{c}1.071 * * * \\
(0.204)\end{array}$ & $\begin{array}{l}1.116 * * \\
(0.539)\end{array}$ \\
\hline Constant & $\begin{array}{c}6.246^{* * * *} \\
(0.130)\end{array}$ & $\begin{array}{c}6.334 * * * \\
(0.098)\end{array}$ & $\begin{array}{c}6.470 * * * \\
(0.079)\end{array}$ & $\begin{array}{c}6.522 * * * \\
(0.092)\end{array}$ & $\begin{array}{c}6.622 * * * \\
(0.233)\end{array}$ \\
\hline Observations & 40 & 45 & 60 & 75 & 125 \\
\hline$R^{2}$ & 0.899 & 0.905 & 0.857 & 0.753 & $\cdot$ \\
\hline Sample & $1880-1915$ & $1880-1920$ & $1880-1935$ & $1880-1950$ & $1880-2000$ \\
\hline
\end{tabular}

Standard errors in parentheses

Treatment group countries are Argentina and Chile, while control group countries are Brazil, Colombia and Peru ${ }^{*} p<0.1, * * p<0.05, * * * p<0.01$ 
Table 4 shows the results for the estimation of the relationship between education and per capita GDP, and also the regression of GDP per capita in our previous Diff-in-Diff model as an instrumental variable of years of education. The last column includes the entire sample while the rest include different subperiods. We can see that the impact of education on the growth in per capita GDP is positive and significant in most cases, although the results are not as robust as for education. As a general conclusion, however, we can see that in Latin American countries the gains observed in education, which are more pronounced in the treatment group, had a positive effect on per capita GDP growth.

We conclude from our natural experiment that the implementation of measures to foster education up to 1890 had a positive effect on the evolution of education during the $20^{\text {th }}$ century being Southern Cone countries the leaders of this process. The growth in educational attainment had further consequences for economic growth We were able to avoid the effect of the endogeneity of education by means of a Diff-in-Diff model that provided us with the instrument for the regression in table 4 . Increased education, especially in the treatment group, leads to growth in per capita GDP, at least over the short term.

\section{Latin America's Education Attainment in an International Comparative Perspective}

In tables 12 and 13 of the appendix we present the results of educational variables at the continental level for years 1950-2000. The results are weighted by country population size. As we can see in these tables, all educational variables improved for all continents from 1950 to 2000, independently of their income levels. The growth path in Latin America shows a period of convergence in educational variables, which is consistent with the global convergence across the world (Sala-i-Martin 2006). It is also consistent with the trend outlined in the introduction of a decrease in the percentage of the population living in poverty. This world-wide movement after the ending of World War II came at a time of decolonization and extended international cooperation in most parts of the world.

In this context of the convergence and global increase in educational levels, Latin America holds an intermediate position between countries of Europe and North America, at the top, and countries of Asia and Africa, at the bottom.

\section{Conclusions}

The twentieth-century saw major improvements throughout Latin America in educational attainment, as well as in several measures of health and GDP per capita. These positive developments were also found in most parts of the world, although with some differences in timing, rates of change, and levels at the end of the twentieth century. Thus, despite variations in political, economic, and social occurrences, certain basic changes in society were not unique to Latin America, but rather were responses to certain world-wide changes in ideology and belief. Why these occurred throughout the world at this time still remains something of a mystery.

Latin American changes were not uniform although all nations experienced improvements in educational attainment, per capita GDP, life expectancies, and health. The nations of the Sothern Cone -Argentina, Uruguay, and Chile-, with their majority white populations ranked the highest in all measures at the start and at the end of the period, while those in Central America, with a generally large share of its population composed of indigenous peoples did worse. In terms of educational attainment, as measured by average years of education, Central America, and, frequently Brazil and Mexico, with large populations of black and indigenous peoples were generally below the levels of other Latin American nations. While the educational performance of these non-white populations increased over time they remained relatively low. Thus the direct and indirect impact of having a large non-white population have had, and still do have, a negative impact upon the quantity, quality, and equitable distribution of education. While much attention has long been given to racial inequalities in the United States, this remains a problem to be confronted throughout Latin America, which still suffers as does the United States, from problems of racial discrimination and segregation despite a recent series of legislative, executive, and judicial attempts to end them.

\section{Acknowledgements}

We want to acknowledge Ana Rodriquez Gonzalez for excellent research assistance and financial support by the Ministry of Economics and Competitiveness project HAR2015-68183-P(MINECO/FEDER)

\section{References}

Alvaredo, G. (2015). Recent Trends in Inequality and Poverty in developing Countries. In Handbook of Income Distribution, ebook, vol II. https://doi.org/10.1016/B978-0-444-59428-0.00010-2

Arroyo Abad, L. (2016). Limits to Estado Docente, Revista de Historia Económica. Journal of Iberian and Latin American Economic History, (1). 
Baizan, P., \& Camps, E. (2007). The Impact of Women's Educational and Economic Ressources on Fertility. Spanish Birth Cohorts, 1901-1950. In A. Janssens (Ed.), Gendering the Fertility Decline in the Western World. Bern, Peter Lang.

Balcazar, C.F., Narayan, A., \& Tiwari, S. (2015). Born with a Silver Spoon: Inequality in Educational Achievement Across the World. Policy Research Working Paper, 7152, World Bank group, January. https://doi.org/10.1596/1813-9450-7152

Barro, R.J. (2012, May). Human Capital and Growth. American Review Papers and Proceedings, 113(2).

Barro, R.J., \& Lee. J.W. (2013). A New Data Set of Educational Attainment in the World, 1950-2010. Journal of Development Economics, Elsevier, 104C, 184-198. https://doi.org/10.1016/j.jdeveco.2012.10.001

Batten, J., \& Mumee. (2010). Educational Inequality from $15^{\text {th }}$ to $20^{\text {th }}$ Centuries, Revista de Historia Económica. Journal of Iberian and Latin American Economic History, (2)

Becker, G.S. (1964). Human Capital. A Theoretical and Empirical Analysis with Special Reference to Education, New York.

Bertola, L., \& O’Campo, J.A. (2013). El desarrollo económica de América Latina desde la Independencia. Fondo de Cultura Económica, México.

Brisdall, N., Lusting, N., \& Meyer, C. (2014). The Strugglers: The New poor in Latin America?. World Development, 60, 132-146. https://doi.org/10.1016/j.worlddev.2014.03.019

Bucciferro, J. (2014). Race and Brazilian Inequality in the Lon Run. Paper presented at the Conference Latin American Inequality in the Lon Run, Buenos Aires, December.

Camps, E. (2016). The Impact of Investment in Human Capital on Economic Development. An Empirical Exercise Based on height and Years of Schooling in Spain (1881-1998), Barcelona Graduate School of Economics Working Papers Series.

Camps, E., \& Engerman, S. (2016). The Impact of Race and Inequality on Human Capital Formation in Latin America during 19th and $20^{\text {th }}$ centuries. Barcelona Graduate School of Economics Working Papers Series.

De Carvalho Filho, I, \& Colisete, R.P. (2013). Education Performance: Was it all Determined 100 Years Ago? Evidence from Sao Paulo, Brazil. Seminarios de Pos-Graduaçao, Univerisdade Federal de Juiz de Fora, Julho.

Engerman, S., \& Sokoloff, K. (2012). Economic Development in the Americas since 1500. Endowments and Institutions. New York, Cambridge University Press-NBER.

Frankema, E. (2009). Has Latin America Always Been Unequal? A Comparative Study of Asset and Income Inequality in the Long $20^{\text {th }}$ Century, Leiden, Koninklijke. https://doi.org/10.1163/ej.9789004175914.i-294

Frankema, E. (2009b). Expansion of Mass Education”, Revista de Historia Económica. Journal of Iberian and Latin American Economic History, 3.

Lucas, R.E. (2002). Lectures of Economic Growth, Cambridge Mass.

Prados de la Escosura, L. (2015, May). Human Development as Positive Freedom: Latin America in Historical Perspective. EHES Working Papers in Economic History, n. 77.

Reimers, F. (2006). Education for Social progress. In Blumer-Thomas, V., Coatsworth, J., \& Cortés Conde, J. (Eds.), The Cambridge Economic History of Latin America (Vol. 2, pp. 427-480). New York, Cambridge University Press. https://doi.org/10.1017/chol9780521812900.013

Sala-i-Martin, X. (2006, May). The World Distribution of Income: Falling Poverty and Convergence Period. Quarterly Journal of Economics, 121(2). https://doi.org/10.1162/qjec.2006.121.2.351

Valente, R.R., \& Berry, B.J.L. (2015, July). Countering Inequality: Brazil Movimento Sem-Terra. Geogaphical Review, 105(3), 1-20. https://doi.org/10.1111/j.1931-0846.2015.12078.x 


\section{Appendix of Tables}

Country Groups

1. Big countries: Mexico and Brazil

2. Southern Cone: Argentina, Chile, Uruguay.

3. Andean countries: Colombia, Peru, Venezuela.

4. Central America: Costa Rica, El Salvador, Guatemala, Honduras, Nicaragua.

5. Others: Bolivia, Ecuador, Panama, Paraguay, Republica Dominicana and others.

(Av. years of schooling population aged 15 or more).

Year 2000. Table 5

\begin{tabular}{cccccc}
\hline & 1 & 2 & 3 & 4 & 5 \\
\hline GDP per cap & 6346.465 & 8983.243 & 5840.357 & 3240.83 & 4518.676 \\
\hline Life E & 72.225 & 75.146 & 71.312 & 70.989 & 69.625 \\
\hline Educational Gini & 28.089 & 15.518 & 26.807 & 30.546 & 30.811 \\
\hline Av years educ & 7.785 & 8.896 & 7.242 & 5.786 & 7.596 \\
\hline Illiteracy & 12 & 3.06 & 8.333 & 23 & 15.28 \\
\hline Av years prim sch & 4.09 & 5.529 & 4.181 & 3.817 & 4.162 \\
\hline Av years sec sch & 2.009 & 2.468 & 2.285 & 1.287 & 2.065 \\
\hline Av years univ & 0.33 & 0.415 & 0.551 & 0.312 & 0.389 \\
\hline
\end{tabular}

Year 1950. Table 6

\begin{tabular}{cccccc}
\hline & 1 & 2 & 3 & 4 & 5 \\
\hline GDP per cap & 2018.371 & 4438.621 & 3947.144 & 1693.2 & 1592.999 \\
\hline Life E & 49.266 & 60.64 & 48.51 & 44.541 & 48.836 \\
\hline Educational Gini & 53.122 & 25.175 & 53.166 & 60.614 & 54.26 \\
\hline Av years educ & 2.857 & 4.884 & 2.662 & 1.898 & 2.863 \\
\hline Illiteracy & 45.5 & 15.8 & 45.333 & 54.4 & 49.571 \\
\hline Av years prim sch & 1.676 & 3.748 & 1.617 & 1.657 & 2.029 \\
\hline Av years sec sch & 0.35 & 0.63 & 0.4 & 0.171 & 0.315 \\
\hline Av years univ & 0.04 & 0.076 & 0.046 & 0.027 & 0.039 \\
\hline
\end{tabular}

Year 1900 Table 7

\begin{tabular}{cccccc}
\hline & 1 & 2 & 3 & 4 & 5 \\
\hline GDP per cap & 998.543 & 2429.321 & 728.0142 & 34.7 & 33.112 \\
\hline Life E & 26.65 & 34.025 & & 64.575 & 68.958 \\
\hline Educational Gini & 81.39 & 53.313 & 73.62 & 1.618 & 1.504 \\
\hline Av years educ & 0.624 & 1.668 & 0.933 & 74.50 & 73.00 \\
\hline Illiteracy & 70.50 & 49.00 & 71.33 & & 72 \\
\hline
\end{tabular}

Values = average values for each country group.

GDP per capita $=$ in $1990 \$$ 
Table 8. Elasticities of Gdp per Capita with Respect to the Average Years of Schooling

(Log GDP per capita/Log Av. Years of Schooling)

\begin{tabular}{lrrrrr}
\hline & 1 & 2 & 3 & 4 & 5 \\
\hline Year 1900 & -13.83 & 16.569 & 6.868 & 11.915 \\
\hline Year 1950 & 7.594 & 5.362 & 9.463 & 12.614 & -4.737 \\
\hline Year 2000 & 4.262 & 4.173 & 4.387 & 4.576 & 4.224 \\
\hline
\end{tabular}

INTERNATIONAL COMPARISONS:

(Average values for populations aged 25 or over)

Year 2000 Table 9

\begin{tabular}{lcccccc}
\hline & Asia & LA & Africa & North A. & Europe & Austr., Malaysia, Indon. \\
\hline Av years of educ & 6.58 & 7.11 & 4.08 & 11.95 & 10.06 & 8.17 \\
\hline Av. years prim sch & 3.61 & 4.66 & 2.85 & 5.83 & 5.76 & 5.07 \\
\hline Av. years sec sch & 2.57 & 2.11 & 1.13 & 4.90 & 3.69 & 2.66 \\
\hline Av. years univ & 0.38 & 0.34 & 0.09 & 1.21 & 0.69 & 0.43 \\
\hline
\end{tabular}

Year 1950 Table 10

\begin{tabular}{lcccccc}
\hline & Asia & LA & Africa & North A. & Europe & Austr., Malaysia, Indon. \\
\hline Av years educ & 1.90 & 2.92 & 0.88 & 7.76 & 4.88 & 3.59 \\
\hline Av years prim sch & 1.32 & 2.52 & 0.74 & 5.06 & 4.10 & 2.63 \\
\hline Av years sec sch & 0.53 & 0.34 & 0.12 & 2.34 & 0.69 & 0.87 \\
\hline Av years univ & 0.06 & 0.04 & 0.01 & 0.34 & 0.08 & 0.08 \\
\hline
\end{tabular}

Year 1960 Table 11

\begin{tabular}{lcccccc}
\hline & Asia & LA & Africa & North A. & Europe & Austr., Malaysia, Indon. \\
\hline Av years educ & 2.33 & 3.31 & 1.07 & 8.48 & 5.42 & 4.12 \\
\hline Av years prim sch & 1.56 & 2.79 & 0.90 & 5.23 & 4.4 & 2.96 \\
\hline Av years sec sch & 0.68 & 0.45 & 0.14 & 2.78 & 0.92 & 1.05 \\
\hline Av years univ & 0.07 & 0.061 & 0.01 & 0.46 & 0.10 & 0.10 \\
\hline
\end{tabular}

RESULTS WEIGHTED BY POPULATION SIZE:

Table 12 Year 2000

\begin{tabular}{lcccccc}
\hline & Asia & LA & Africa & North A. & Europe & Austr., Malaysia, Indon. \\
\hline Av years educ & 5.89 & 6.69 & 4.25 & 12.72 & 10.14 & 6.11 \\
\hline Av years prim sch & 3.81 & 4.30 & 2.94 & 5.91 & 5.40 & 4.12 \\
\hline Av years sec sch & 1.83 & 2.03 & 1.20 & 5.30 & 3.90 & 1.69 \\
\hline Av years univ & 0.25 & 0.35 & 0.11 & 1.5 & 0.72 & 0.28
\end{tabular}

Year 1950 Table 13

\begin{tabular}{lcccccc}
\hline & Asia & \multicolumn{1}{l}{ LA } & Africa & North A. & Europe & Austr., Malaysia, Indon. \\
\hline Av years educ & 1.20 & 2.50 & 0.90 & 8.07 & 4.83 & 1.84 \\
\hline Av years prim sch & 0.97 & 2.10 & 0.74 & 5.09 & 4.30 & 1.4 \\
\hline Av years sec sch & 0.20 & 0.36 & 0.14 & 2.65 & 0.68 & 0.39 \\
\hline Av years univ & 0.02 & 0.04 & 0.016 & 0.41 & 0.07 & 0.05 \\
\hline
\end{tabular}

